\title{
Avaliação microbiológica da água de consumo empregada em unidades de alimentação
}

\author{
Microbiological evaluation of drinking water used in feeding units
}

\author{
Leonardo Pereira de Siqueira $^{1}$ \\ N eide KazueSakugawa Shinohara ${ }^{2}$ \\ Rosália Maria Torres de Lima ${ }^{3}$ \\ José do Egito dePaiva ${ }^{2}$ \\ José Luiz de Lima Filho ${ }^{1}$ \\ IrineideTeixeira de Carvalho ${ }^{2}$
}

${ }^{1}$ UniversidadeFederal Rural dePernambuco,

Departamento de

Tecnologia Rural.

RuaDom Manuel de

M edeiross/n, Dois Irmãos.

52171-900 Recife PE.

Ip_siqueira@yahoo.com.br

${ }^{2}$ Departamento de

Tecnologia Rural, UFRPE.

${ }^{3}$ Graduação em

Gastronomia, UFRPE.
Abstract The water for human consumption is the main vehicle for the transmission of pathogens that are capable of causing enteric parasitic diseases; therefore, its microbiological control is vital. This work had the purpose of evaluating the bacteriological quality of drinking water, in terms of the presence of total and thermotolerant coliforms, in different Feeding U nits in the city of Recife, Pernambuco State, according to the potableness standards established by O rdinanceN 0.518 of 2004 of the Brazilian M inistry of $\mathrm{H}$ ealth/ANVISA. Forty water samples were collected in the Feeding U nits located near the UFPE and U FRPE. The bacteriological tests for research on total and thermotolerant coliforms were carried out in accordance with the protocol of APHA (1995). Of the analyzed samples, $62.5 \%$ presented total coliforms and $42.5 \%$ thermotolerant coliforms. According to the results obtained, $62.5 \%$ of the samples are not in compliance with the law in force.

Key words Drinking water, Total coliforms, Thermotolerant coliforms
Resumo $\mathrm{A}$ água deconsumo humano éo principal veículo de transmissão de patógenos capazes de causar infecções gastrointestinais, sendo vital o seu controle microbiológico. 0 presente trabaIho teve a finalidade de avaliar a qualidade bacteriológica da água para o consumo humano, quanto à presença de coliformes totais e termotolerantes, em diferentes unidades de alimentação na cidade do Recife (PE), conforme os padrões de potabilidadeestabelecidos pela Portaria ${ }^{\circ} 518$ de 2004 do M inistério da Saúde/ANVISA. Foram coletadas quarenta amostras de água em unidades de alimentação, localizadas no entorno da U niversidade Federal de Pernambuco e da U niversidade Fe deral Rural de Pernambuco. Foram realizados os testes bacteriológicos para pesquisa de coliformes totais e termotolerantes, conforme o protocolo do APH A (1995). Das amostras analisadas, $62,5 \%$ apresentaram coliformes totais e $42,5 \%$, coliformestermotolerantes. Deacordo com os resultados obtidos, $62,5 \%$ das amostrasnão estão em conformidade com a legislação vigente. Palavras-chave Água de consumo, Coliformes totais, Coliformes termotolerantes 
Introdução

As transformações no mundo contemporâneo provocaram mudanças si gnificativas na alimentação e nos hábitos alimentares dos seres humanos, que passaram a usufruir cada vez menos do universo doméstico. Essas mudanças foram ocasionadas por fatores que perpassam a urbanização, a industrial ização, a el evação do nível de vida e de educação, 0 acesso mais amplo da população ao lazer, a redução do tempo para o preparo e/ou consumo do alimento, as viagens, entre outros fatores ${ }^{1}$.

Para 0 alimento se tornar fonte de saúde imprescindível ao ser humano, deve ser processado dentro de um controle de etapas, utilizando-se matéria-prima de boa qualidade, em condições higiênico-sanitárias satisfatórias, e sendo convenientemente armazenado etransportado. Quando não obedecidas essas condições, ele podetornar-se fonte de doenças².

As unidades de alimentação que adotam um programa de controle das etapas são capazes de analisar e avaliar a preparação do alimento durante o processo, desde a matéria-prima até 0 produto acabado. Dessa forma, pode-se obter uma melhoria na qualidade e uma minimização dos riscos de um surto de origem alimentar ${ }^{3}$.

A incidência de doenças relacionadas ao consumo dealimentos cresceanualmente; o número de refeições realizadas fora de casa potencializa o surgimento dedoenças transmitidas por alimentos (DTA) e, consequentemente, os surtos de toxinfecções alimentares ${ }^{4}$. Para Smith e Fratamico, o consumo de refeições fora do domicílio é um dos fatores que mais contribuiu para 0 aumento da ocorrência de DTA, uma vez que, nas unidades de alimentação, as refeições são produzidas em larga escala e torna-se mais difícil o controle efetivo de todas as preparações produzidas ${ }^{5}$.

As DTA são caracterizadas por um conjunto deperturbações gástricas, envolvendo geralmente vômitos, quadros diarréicos, febres e dores abdominais ${ }^{6}$. Podem ser provocadas por diversos grupos de microrganismos, incluindo bactérias, fungos, protozoários e vírus. As bactérias, pela sua diversidade e patogenia, constituem, de longe, o grupo microbiano mais importante e mais intimamente associado às doenças transmitidas por alimentos ${ }^{7}$. Os salimentos de forma geral podem ser contaminados por bactérias patogênicas e transmitidas para o homem, como resultado das precárias condições higiênico-sanitárias durante 0 seu processamento ${ }^{8}$.

Conforme Panza et al. ${ }^{9}$, a maioria das unida- des de alimentação no Brasil não possui um responsável técnico pelo controle da higienee qualidade na prestação de serviços. Este fato traz consequências sérias em termos de segurança sanitária, pois os índices de doenças veiculadas por alimentos vêm aumentando, tanto em países em desenvolvimento como em países desenvolvidos ${ }^{10}$.

De acordo com a Portaria n ${ }^{\circ} 518$ de 2004 do M inistério da Saúde/ANVISA, a água é considerada potável, sob o ponto de vista microbiológico, quando está de acordo com a seguinte conformidade: ausência de coliformes totais e termotolerantesem $100 \mathrm{~mL}$ deamostra deágua para consumo

0 presente trabal ho teve a finalidade de avaliar a qualidade microbiológica da água para o consumo humano, quanto à presença de coliformes totais e termotolerantes, em diferentes unidades dealimentação da cidadede Recife(PE), conforme os padrões de potabilidade estabelecidos pela Portaria ${ }^{\circ} 518$ de 2004 do M inistério da Saúde/AN VISA ${ }^{11}$.

\section{Material e métodos}

As colheitas foram realizadas entre os meses de março e abril, abrangendo quarenta unidades de alimentação localizadas no entorno da Universidade Federal Rural de Pernambuco (UFRPE) e daUniversidadeFederal dePernambuco (UFPE). Essas unidades são abastecidas pela rede de distribuição pública ${ }^{12} \mathrm{e} o$ armazenamento interno é feito por meio de cisternas e/ou caixas-d'água.

\section{Coleta do material}

0 procedimento de coleta seguiu o protocolo conforme o Standard M ethods for the Examination of Water and Wastewater ${ }^{13}$. Os recipientes para a coleta foram lavados, secose, em seguida, adicionados de $0,1 \mathrm{~mL}$ de tiossulfato de sódio $\left(\mathrm{Na}_{2} \mathrm{~S}_{2} \mathrm{O}_{3}\right)$ a $10 \%$ para cada $100 \mathrm{~mL}$ de água a ser coletada. A adição desse composto ao frasco teve por finalidade impedir a ação do cloro residual. Posteriormente, os frascos foram esterilizados a $121^{\circ} \mathrm{C}$ por 21 minutos ${ }^{14}$. A assepsia das torneiras dos locais de coleta foi realizada com solução de álcool iodado ( $2 \%$ ), por meio depulverização por dentro e por fora e depois se abriu a torneira por alguns minutos ${ }^{13}$. As amostras foram coletadas de um único ponto de saída de água empregado em cada estabelecimento para realização das preparações culinárias, essas acondicionadas em caixas isotérmicas e encaminhadas ao laboratório. 
Pesquisa de coliformes totais

Todas as amostras foram submetidas a um ensaio presuntivo utilizando-se o teste presençaausência (PA). Este teste qualitativo é uma modificação simples da técnica dos tubos múltiplos e se baseia na capacidade das bactérias do grupo coliforme em fermentar a lactose, produzindo, assim, ácidos e gases que irão ser evidenciados nesse procedimento. Cada $100 \mathrm{~mL}$ de amostras foram vertidos cuidadosamente em recipientes contendo $50 \mathrm{~mL}$ de caldo PA triplo, acondicionados em um recipienteestéril com seus respectivos tubos de Durhan invertidos e posteriormente incubados a $35^{\circ} \mathrm{C} \pm 0,5$ por $24 / 48$ horas em estufa bacteriológica. Foram consideradas positivas as amostras que apresentaram reação presuntiva positiva, observada pela mudança de coloração do meio (de púrpura para amarelo) e pela produção de gás. As amostras positivas para o teste PA foram submetidas a teste confirmatório em caldo lactose verde brilhante bile $2 \%(C L V B B)^{13}$.

Pesquisa de coliformes termotolerantes

Em seguida, as amostras que evidenciaram formação de gás em CLVBB foram inoculadas em tubos de ensaio conten do $10 \mathrm{~mL}$ de caldo EC e incubadas em banho-maria a $44,5^{\circ} \mathrm{C} \pm 0,2$ por $24 / 48$ horas. Essa última etapa teve por objetivo a pesquisa de coliformes termotolerantes ${ }^{13}$.

\section{Resultadosediscussão}

A Portaria no 518 do M inistério da Saúde ${ }^{11}$ estabelece como padrão de potabilidade, para a água destinada ao consumo humano, a ausência de bacté rias do grupo dos coliformes termotolerantes, anteriormente denominados coliformes fecais.

$\mathrm{Na}$ Tabela 1, observa-se que $62,5 \%$ das amostras analisadas apresentaram coliformes totais.

Tabela 1. Avaliação microbiológica das águas de consumo em unidade de alimentação.

\begin{tabular}{lcccccc}
\hline $\begin{array}{l}\text { Número de } \\
\text { unidades de } \\
\text { alimentação }\end{array}$ & $\begin{array}{c}\text { Coliformes } \\
\text { totais }\end{array}$ & & \multicolumn{2}{c}{$\begin{array}{c}\text { Coliformes } \\
\text { termotolerantes }\end{array}$} \\
\cline { 2 - 3 } & & $n^{*}$ & $\% * *$ & & $n^{*}$ & $\% * *$ \\
\hline 40 & 25 & 62,5 & & 17 & 42,5 \\
\hline
\end{tabular}

$*_{\mathrm{n}}=$ número de $a m o s t r a s, * * \%$ = frequência de amostras.
Portanto, essas amostras são consideradas impróprias para o consumo humano segundo a citada portaria. A presença de coliformes na água indica poluição, com o risco potencial da presença de organismos patogênicos, e sua ausência é evidência de umaágua bacteriologicamentepotável, uma vez que são mais resistentes na água que as bactérias patogênicas de origem intestinal ${ }^{15}$.

Embora não exista limitação para o número de coliformes totais presentes na água potável, esta mesma portaria sugere que, quando for verificada a presença de coliformes totais e ausência de coliformestermotolerantes, sejam tomadas providências imediatas de caráter corretivo e preventivo, como limpeza das caixas d'água e cisternas.

Conforme ainda a Tabela 1, 42,5\% das águas pesquisadas apresentaram positividade para coliformes termotolerantes. Esses resultados se mostram acima dos descritos por Nogueira et al. ${ }^{16}$ para águas tratadas pelo sistema público e coletadas na região de $M$ aringá (PR). A presença dessas bactérias está representada quase na sua totalidade por Escherichia coli, o que é extremamente preocupante, haja vista que esse microrganismo pode acometer desde uma simples gastroenterite ou evoluir até casos letais, principalmente em crianças, idosos, gestantes e imunodeprimidos ${ }^{7}$. Esse fato ainda chama a atenção para a necessidade de monitoramento da qualidade microbiológica das águas empregadas na produção de refeições, pois estas mesmas, se não estão em conformidade com a legislação vigente, poderão levar a surtos de toxinfecção alimentar aos comensais.

A água pode ser contaminada no ponto de origem, durante a sua distribuição e, principalmente, nos reservatórios particulares, sejam eles de empresas ou domiciliares. Segundo Germano e Germano $0^{17}$, as causas mais frequentes da contaminação da água nesses reservatórios são vedação inadequada das caixas d'água e cisternas, e carência de um programa de limpeza e desinfecção regular e periódica.

A garantia da qualidade microbiológica da água de consumo empregada nessa pesquisa está sob a responsabilidade da COM PESA/PE. Deste modo, supõe-se que a água que chega aos estabelecimentos estudados está em conformidade com os padrões microbiológicos estabelecidos pela legislação. Entretanto, os resultados obtidosindicam que um grandepercentual deamostras está contaminado com material de origem fecal. Essefato provavelmentedeveser decorrente de uma não adoção de boas práticas físicosanitárias nos reservatórios por parte das em- 
presas avaliadas. Estes estabelecimentos deveriam visar à manutenção da água nos padrões sanitários ideais, para não se constituir em um fator de risco aos comensais.

\section{Conclusões}

Em $62,5 \%$ das amostras analisadas, foi detectado desacordo com os padrões microbiológicos legais, por apresentarem contaminação por coliformes totais, sugerindo condições higiênico-sanitárias precárias.

De acordo com os resultados obtidos, recomenda-se a adoção de um programa de educação sanitária para a conscientização nas unidades de alimentação estudadas, quanto à importância da higi enização de seus reservatórios internos.

\section{Referências}

1. Akutsu RC, Botelho RA, Camargo EB, Sávio KEO, Araújo WC. Adequação das boas práticas de fabricação em serviços de alimentação. Rev Nutr. 2005; 18(5):669-680

2. Bobeng BJ, David BD. HACCP: models for quality control of entrée production in food service systems. J Food Prot 1977; 40(9):632-38.

3. Cummings AR. Quality control principles: applications in dietetic practice. J Am Diet Assoc 1992; 92(4):427-428.

4. Lynch RA, Elledge BL, Griffith CC, Boatright DT. A comparison of food safety knowledge among restaurant managers, by source of training and experience, in Oklahoma County. J Environ Health 2003; $66(2): 9-14$

5. Smith DL, Fratamico PM. Factors involved in the emergence and persistence of food diseases. J Food Prot 1997; 40(6):415-422.

6. Jay JM. M icrobiologia de alimentos. 6a ed. Porto Alegre: Acribia; 2005.

7. Franco DGMF, Landgraf M. Microbiologia dos alimentos. 2 2 ed. São Paulo: Atheneu; 2007.

8. Antunes LAF. Qualidade microbiológica de leite cru. Revista do Instituto de Laticínios Cândido Tostes 1996; 41(244):20-24.

9. Panza SG, Andreotti A, Baleroni FH, Paroschi VHB. Importância do treinamento para manipuladores de alimentos em relação à higiene pessoal. Iniciação Científica Cesumar 2003; 5(1):29-33.

10. Rego JC, Stamford TLM, Pires EM F, Silva Jr. EA Proposta de um programa de boas práticas de manipulação e processamento de alimentos para unidades de alimentação e nutrição. Higiene Alimen$\operatorname{tar} 2001 ; 15(89): 22-27$.

\section{Colaboradores}

LP Siqueira e NKS Shinohara trabalharam na pesquisa, concepção e redação final. RM T Lima e IT Carvalho trabal haram na pesquisa e metodologia. JE Paiva trabalhou na concepção eredação final e Lima Filho JL trabalhou na metodologia e redação final.

\section{Agradecimentos}

Agradecemos à UFRPE, UFPE e ao Laboratório deAlimentos/DTR/UFRPE.
11. Brasil. M inistério da Saúde. Secretaria de Vigilância Sanitária. Portaria n 518 de 25 de março de 2004. Diário O ficial da União 2004; 26 mar.

12. Compesa. [site da Internet]. [acessado 2007 abr 02]. Disponível em: http://www.compesa.com.br

13. American Public Health Association. Standard M ethods For The Examination of Water and Wastewater. $19^{\text {th }}$ ed. Baltimore: United Book Press, Inc.; 1995.

14. Feitosa A, Silva JL, M oura GJB, Calazans GMT. Avaliação da Qualidade da Água Potável em Escolas da Rede Pública em Recife-PE/Brasil. Higiene Alimentar 2006; 20(139):80-82.

15. Cabrini KT, Gallo CR. M icrobiological quality of spring mineral water and bottled mineral water. In: Anais do XXI Congresso Brasileiro de Microbiologia. Rio de Janeiro : Armazém das Letras, 2001. v. 1. p. 406-406.

16. Nogueira G, Nakamura CV, Tognim MC, Abreu Filho BA, Dias Filho BP. Microbiological quality of drinking water of urban and rural communities. Rev. Saude Publica 2003; 2(37):232-236.

17. Germano PML, Germano MIS. Higiene e vigilância sanitária de alimentos. São Paulo: Varela; 2003.

Artigo apresentado em 28/08/2007

A provado em 03/01/2008

Versão final apresentada em 21/02/2008 